STATE OH ALASKA

DWXARTMENT OF NATURAX, RESOURCLS

SR 28

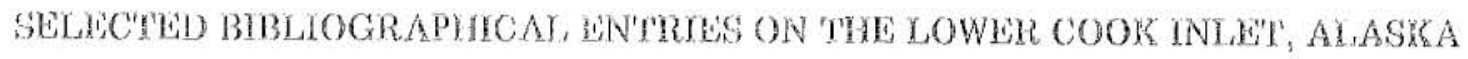

Compiled by K.S. Lmmel and P.I. Coonrod

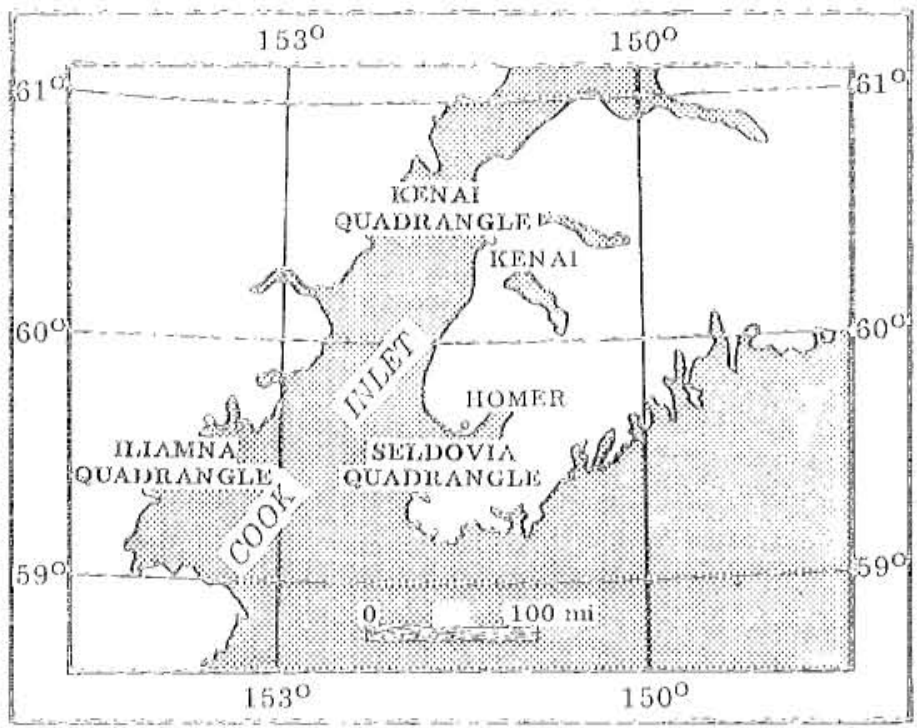

Published by

DIVISION OI* GEOLOGICAI, \& GEOPHYSICAL SURVEYS

Anchorage, Alaska

3981

ROSS G, SCIIAFF

STATL GLOLOGIS 
SELECTED BIBLIOGRAPHICAL ENTRIES ON THE LOWER COOK INLET, ALASKA

Compiled by K.S. Emmel and P.L. Coonrod 
Jay S. Hammond, Governor

John W. Katz, Commissioner, Dept. of Natural Resources Geoffrey Haynes, Deputy Commissioner

Available from Alaska Division of Geological and Geophysical Surveys, P.O. Box 80007, College, 99708; 941 Dowling Rd., Anchorage. 99502: P,O. Box 7438, Ketchikan, 99901: and 230 So. Franklin St. (Rm 407), Juneau, 99801. Price $\$ 1$. 


\section{Selected bibliographical entries on the lower Cook Inlet, Alaska}

This bibliography includes most of the geological literature on the area of Cook Inlet between $59^{\circ}$ and $61^{\circ} \mathrm{N}$. latitude (fig. 1). Both onshore and off-shore reports are listed. Emphasis is placed on petroleum-related material, including geophysics, stratigraphy, paleontology, and articles fron the petro-

leum trade journals. Mining and hard-rock geology are represented, but no effort has been made to include all literature in these fields.

Entries were obtained primarily from the Index and Bibliography of Geology and from the Bibliography of the Cook Inlet, 1969-1976 (IIcGee and others, 1977). Reference lists of many reports were also examined. No attempt was made to verify information by examining all of the titles listed. Consequently, any corrections or additions will be welconed by the authors.

The index is intended as a guide in the literary search. Only the title of an article was considered in indexing.

Karen S. Emmel Patti L. Coonrod 
INDEX

AREAS

Alaska Peninsula: Kelley, J.S., and Denman, J.M., 1972

Augustine Is. (see also volcanology): Detterman, D.L., and Jones, D.L., $1973 ; 1974$

Cook Inlet: Bouma, A.H., and Hampton, M.A., 1976; Bouma, A.H., and Wennekens, M.P., 1977; Bouma, A.H., and others, 1978a; 1978b; Bouma, A.H., and Hampton, M.A., 1978, Fisher, M.A., 1976, 1977; Fisher M.A., and Magoon. L.B., 1978; Hampton, M.A., and Bouma, A.i., 1979; Hayes, J.B., and others, 1976; Hayes, M.O., Brown, P.J., and Miche1, J.A., 1976a; 1976b; Hein, J.R., and others, 1979; Karlstrom, T.N.V., 1965; Kelley, T.E., 1963a; 1963b; 1966; 1968; Kinney, P.J., Groves, J., Bulton, D.K., 1970; Kirschner, C.F., and Lyon, C.A., 1973; Lian, H.M., and Simonson, R.R., 1962; Magoon, L.B., and Claypool, G.E., 1978; Magoon, L.B., Egbert, R.M., and Petering, George, 1978; McGee, D.L., 1977; Muench, R.D., Mofield, H.0., and Charme11, R.L., 1978; Stanton, T.W., and Martin, G.C., 1905; VanDelinder, D.G., 1977

Homer: Adkison, W.L., 1975; Waller, R.M., 1966

Iliamna: Detterman, R.L., 1963; Detterman, R.L., and Reed, B.L., 1980; Richter, D.H., and Herreid, Gordon, 1965

Kenai: Cobb, E.H., 1972a; Martin, G.G., Johnson, B.L., and Grant, U.S., 191.5; Reger, R.D., 1977; Reger, R.D., and Carver, C.L., 1977

Seldovia: Cobb, E.H., 1972b

South-Centra1: Reed, B.L., and Lanphere, M.A., 1969; Selkregg, L.L., 1974

Tuxedni Bay: Grantz, Arthur, 1956

Tyonek: Adkison, W.L., Kelley, I.S., Newman, K.R., 1975; Cobb, E.H., 1972 c; Dickenson, K.A., 1978

\section{BIBLIOGRAPHY}

Averitt, P. and Lopez, L., 1972; Kelley, J.S., and Denman, J.M., 1972; Lyle, W.M., and Bragg, N.J., 1974; Maher, J.C., and Trollman, E.M., 1969; McGee, D.L., and others, 1977 
ENVIRONMEN'C (cont'd.)

Wildlife: Smith, R.G., 1973

GEOLOGY

General: Kelley, T.F., 1963a; 1963b; 1966; Martin, G.G, Johnson, B.L. and Grant, U.S., 1915; Osment, F.C., Morrow, R.Y., and Craig, R.W., 1967

Glacial: Karlstrom, T.N.V., 1960; 1964

\section{GEOPHYSICS}

Aeromagnetic surveys: Alaska Div. Geological and Geophysical Surveys, 1973a; 1973b; 1973c; Andreasen, G.E., Zietz, Isidore, and Grantz, Arthur, 1958; Grantz, Arthur, Zietz, Isidore, and Andreasen, G.E., 1963; LKB Resources, 1978; Zletz, Isidore, Andreasen, G.E., and Grantz, Arthur, 1960

Magnetics, general: Grantz, Arthur, and Zeitz, Isidore, 1960

General: Oil and Gas Journal, 1971c; Shor, G.G., Jr., 1962; U.S. Geological Survey, 1976

Gravity: Barnes, D.F., 1968; 1969; 1976; Hackett, S.W., 1975; 1977

High resolution: Petty Ray, 1977; U.S. Geological Survey, 1977

Seismic: Shor, G.G., and von thene, Roland, 1972; Sieck, H.C., and others, 1977; Fisher, M.A., 1976; Hampton, M.A., and Bouma, A.H., $1976 ; 1980$

GEOTHERMAL

Barnes, D.F., and Miller, T.P., 1975

HAZARDS

Tysda1, R.G., 1976; Pulpan, H., and Kienle, Juergen, 1977; 1979

HYDROLOGY

General: Freethey, G.W., 1978; Freethey, G.W., and Scully, D.R., 1980; Scully, D.R., Leveen, L.S., and George, R.S., 1978; U.S. Geological Survey, 1971a

F1oods: Childers, J.M., 1970; Post, Austin, and Mayo, L.R., 1971; Reid, J.K., and others, 1975; U.S. Army Corps of Engineers, 1973; $1974 ; 1975 a$ 
HYDROLOGY (cont'd.)

Kenai: Anderson, G.S, 1971; Anderson, G.S., and Jones, S.H., 1972a; $1972 b$

Soldotna: Anderson, G.S., 1972

MAPS

Geologic:

Alaska: general - Bennison, A.P. 1974

southeast - Beikman, H.M., 1975a

southwest - Beikman, H.M., 1974

Alaska Peninsula: Beikman, H.M., 1975b; Jones, D.L., and

Miller, J.W., 1976

Augustine Is.: Detterman, R.L., 1963

Cook Inlet: Beikman, H.M., 1974

Iliamna: Detterman, R.L., 1964

Sedimentary basins: Chase, T.E., and others, 1980

MINERALS

Genera1: Race, W.H., 1962

Yagnetite: Grantz, Arthur, 1956

Metalliferous: Berg, H.C., and Cobb, E.H., 1967

Mineral Fuels: Grantz, Arthur, 1964

Resources: Cobb, E.H., 1972a; 1972b; 1972c; McKelvey, V.E., and Wang, F.F.H., 1969

Occurrences: Cobb, E.H., 1980a; 1980b

NAVIGATION

Nationa1 Ocean Survey, 1977

\section{OCEANOGRAPHY}

Bouma, A.H., and Wennekens, M.P., 1977; Bouma, A.H., and others, 1978; Bouma, A.H., and Hampton, M.A., 1978; Bouma, A.H., and others, 1978; Bouma, A.H., and others, 1980; Chester, A.J., and others, 1979; Gatto, L.W., 1975; Hampton, M.A., and Bouma, A.H., 1979; Hein, J.R., and others, 1979; Knul1, J.R., 1975; Larrance, J.D., Chester, A.J., and Milburn, H., 1979; Muench, R.D., Mofield, H.O., and Chamel, R.L., 1978; Rappeport, M.L., and others, 1979; 1981; Rosenberg, and others, 1967; Wright, F.F., Sharma, G.D., and Burbank, D.C., 1973 


\section{OIL SPILISS}

Beving, R.T., 1974; Dames and Moore, 1976; 1979; 1980; Hayes, M.0., Brown, P..., and Miche1, J., 1976; LaBel1e, R.P., Samue1s, W.B., and Lanfear, K.J., 1980; Miche1, J., and others, 1978

\section{PALEONTOLOGY}

Ammonites: Imlay, R.W., 1953; 1962a; 1962b; 1964; 1975; 1980

Corals: Churkin, M. Jr., 1975

Foraminifera: Boettcher, R.R., 1975

General: Imlay, R.i., and Detterman, R.L., 1973; Jones, D.L., and Clark, S.H.B., 1973; Wolfe, J.A., 1977; Wolfe, J.A., Hopkins, D.M., and Leopold, E.B., 1966; Wolfe, J.A., and Tanai, Toshimasa, 1980

Mollusks: Addicott, W.O., 1971; 1973

Palynology: Adkison, W.L., 1975; Adkison, W.L., Kelley, J.S., and Newman, K.R., 1975; F.lsik, W.C., 1973; Engelhardt, D.W., 1966; Hedlung, R.W., and Engelinardt, D.W., 1970

Pelecypods: Silberling, N.J., 1963

PETROGRAPHY

Christensen, E.W., 1977; Zuffa, G.G., Nilsen, T.H., and Winkler, G.R., 1980

PE TROLEUM AND NATURAL, GAS

Demand: Bewley, G., 1975; Bewley, G., and others, 1975

Development: Adams, W.D., 1972; Alaska District Corps of Engineers, 1974; Evans, C.D., 1969; Gi11, D., 1975a; Hayes, M.o., Brown, P.J., and Miche1, J.A., 1976b; Hiles, R.M., Gryc, George, and Dobey, P.L., 1975; Jones, B.C., 1979; 1980; Lian, E.B., 1971; Magoon, L.B., 1975; Norgaard, R.B., 1972; Osment, F.C., Morrow, R.M., and Craig, R.W., 1967; Reed, J.C., 1970; Sobiera1ski, V.P., 1968; Sweet, J.M., 1964; U.S. Army Corps of Engineers, 1974; Visser, R.C., 1969

Exploration: Bettis, F., 1976; Blasco, D.P., 1976b; Gill, D., 1975b; Hills, M.L., 1963a; 1963c; Lynch, Maurice, 1980; Magoon, L.B., and Claypool, G.E., 1979; McCaslin, J.C., 1976; Neel, T.H., 1977; Northern Resource Management, 1980; 011 and Gas Journa1, 1974b; 1974c; 1976; 1980; Plafker, George, 1971; Rainwater, E.H., 1966; Wilson, H.M., 1972 
PETROLEUM AND NA'TURAL GAS (cont'd.)

Facilities: Jackson, J.B., and YcIthargey, Erank, 1980

Fields: Alaska Geological Society, 1970; Blasco, D.P., 1974; Boss, R.F., Lennon, R.B., and Wilson, B.W., 1976; Laughbaum, G.H., Jr, 1970; Moody, J.D., Mooney, J.W., and Spivak, J.W., 1970; Murphy, R.J., 1977; Petroleun Data System, 1977; Story, R.F., 1966

General: Blasco, D.P., Wenger, W.J., and Morris, J.C., 1972;

Davidson, K., 1963; Hills, M.A., 1964; Ke1.1y, T.E., 1968; LeMay, W.J., 1969; Lian, A.M., and Simonson, R.P., 1962; Moulton, B., 1972; O11 and Gas Journal, 1960; Wi.tson, H.M., 1980

Leasing: Magoon, L.B., and others, 1979; 0il and Gas Journtl, 1970;

$1971 \mathrm{a} ; 1971 \mathrm{~b} ; 1972 \mathrm{a} ; 1972 \mathrm{~b} ; 1973 \mathrm{a} ; 1973 \mathrm{~b} ; 1974 \mathrm{a} ; 1974 \mathrm{~d} ; 1975 \mathrm{a}$;

$1975 \mathrm{~b} ; 1975 \mathrm{c}$; 1975d; 1975e; U.S. Bureau of Land Management, Alaska Outer Continental. Shelf Office, 1976; Wilson, H.M., 1974

Origins: Claypool, G.E., Threlkeld, L.N., and Magoon, L.B., (in preparation); Hood, A.C., Gutjahr, C.M., and Heacock, R.L., 1975; Magoon, L.B., and Claypool, G.E., (in press)

Potential: Cram, I.H., 1971; Hills, M.L., 1963b; Magoon, L.B., 1976 a

Production: Alaska Division 011 and Gas, 1976

Reserves: Petroleum - Crick, W., 1971

Resources: Energy - Averitt, P., 1970

General - Resource Planning Team, 1974; Weeks, L.G., 1968; Jones, B.C., 1979; 1980

Land policy - Klein, R.M., 1974

Mineral - Cobb, E.H., 1972a; 1972b; 1972c; McKelvey, V.E., and Wang, F.F.H., 1969

011 and Gas: Crick, R.W., 1971; Gryc, George, 1971, Klein, R.M., and others, 1973; Miller, B.Y., and others, 1975; National Petroleum Counci1, 1975; Plafker, George, and others, 1971; von Huene, Roland, Lathram, E.H., and Reimnitz, Erk, 1971

Seeps: Blasco, D.P. 1976a

Statistics: Alaska Division of $0 i 1$ and Gas, 1969; 1970; 1971; 1972; 1973; 1974; 1975; 1976; 1977; Alaska 011 and Gas Conservation Commission, $1978 ; 1979$

We11 Location Maps: Magoon, L.B., Adkison, W.L., and Egbert, R.M., 1976b; Munger, A.H., 1971; U.S. Bureau of Mines, 1973 
PETROLEUN AND NATURAZ GAS (cont'd.)

Petrology: Triplehorn, D.M., 1976

PLATFORM DESLGN

Bea, R.G., and Akky, M.R., 1979; Visser, R.C., 1969

PLU'TONISY

Detterman, R.L., Reed, B.L., and Lanphere, M.A., 1965

RADLOMETRIC, DATING

Karlstrom, T.N.V., 1968

REMO'TE SENSING

Belon, A.E., and Miller, J.M., 1974; Belon, A.E, and Stringer, W.J., 1975; Lathram, E.H., 1972a; Miller, J.M., 1974; Miller, J.M, and Belon, A.E., 1974; Wright, F.F., Sharma, G.D., and Burbank, D.C, 1973

\section{SED TMENTATION}

Das, M.M., 1971; Sharma, G.D., 1969; Sharma, G.D., and Burre11, D.C., 1970

SEISMOLOGY

Alaska Div. Geological and Geophysical Surveys, 1964; Davis, T.N., and Eckols, C., 1962; Estes, S.A., 1978; Fogleman, K., and others, 1978; Foster, Helen, and Karlstrom, T.N.V., 1967; Gedney, Larry, and others, 1972; Lahr, J.C., Engdah1, E.R, and Page, R.A., 1974; Lahr, I.C., Page, R.A., and Thomas, J.A., 1974; Mauk, F.J., and Kienle, Juergen, 1973; National Research Council, 1972; Page, R.A., 1968

\section{S'TRATIGRAPHY}

Alaska Geological Society, 1969; Carter, R.D., and Adkison, W.L. 1972; Church, R.E., and Lian, E.B., 1970; Detterman, R.L., 1963; Dutro, J.T., Jr., 1960; Hartman, D.C., Pesse1, G.H., and McGee, D.L., 1972; Hopkins, D.M., and others, 1965; Jones, D.L., and Detterman, R.L., 1966; Kirschner, C.E., and Lyon, C.A., 1973; Paige, S., and Knopf, A., 1907; Woncik, J., 1968; Wolfe, J.A., Hopkins, D.M., and Leopold, E.B., 1966

\section{S'TRUCTURE}

Crust: Berg, E., 1972; Jones, D.L., 1973

Continental Margin: von Huene, Roland, 1972a; 1972b 


\section{SURFICIAL GEOLOGY}

Kar1stron, T.N.V., 1958; 1964; Reger, R.D., 1977; 1978a; 1978b; 1979; Reger, R.D., and Carver, C.L., 1977; Riehle, J.R., 1977; Rtehle, J.R., and Emme1, K.S., 1980

\section{TECTONICS}

Border Ranges Fault: Mackevett, E.M., Jr., and Plafker, George, 1973; Mackevett, E.M., Jr., 1974a; 1974 b

Bruin Bay - Lake Clark Faults: Detterman, R.L., and others, 1976

Castle Mt. Fal1t: Detterman, R.t., and others, 197ł; 1976

General: Budnik, R.T., 1974b; Gedney, Larry, and Berg, Eduard, 1969; Hackett, S.W., 1976; Jones, D.L., Mackevett, E.M., Ir., and Plafker, George, 1970; Kirschner, C.E., and Lyon, C.A., 1973; Payne, R.G., 1955; Richards, G.H., 1974

Plate Tectonics: Davies, J. and Berg, Eduard, 1973

TSUNAMI

Berg, E., and others, 1971; Spaeth, M.G., and Berkman, S.C., 1969

URBAN GEOLOGY

U.S. Army Corps of Engineers, 1975b

VOLCANOLOGY

Augustine: Johnston, D.A., Schinincke, H.U., and Kienle, Juergen, 1977; Johnston, D.A., 1978; Kienle, Juergen, and Forbes, Robert, 1972; Kienle, Juergen, and Shaw, G.E., 1979; Kienle, Juergen, and Swanson, S.E., 1980; Lalla, D.J., 1974; Mauk, E.J., and Kienle, Juergen, 1973; Meinel, A.B., Meinel, M.P., and Shaw, G.E., 1976; Reeder, J.W., Lahr, J.C., and Thomas, J., 1977; Schmincke, H.U., and Johnston, D.A., 1977; Sobieralski, V.R., 1968; Stith, J.L., Hobbs, P.V., and Radke, L.F., 1977; Wilcox, R.E., 1959; Wrenn, S.C., 1976

Genera1: Johnston, D.A., and Schmincke, H.U., 1977; Pulpan, H., and Kienle, Juergen, 1977

WELL LOG

COST We11s: Christensen, E.W., 1977; Core Laboratories, Inc., 1977a; 1977 b; Schluger, P.R., 1977

Deep Creek Unit: Kelley, J.S., 1973

Capps Coal Field: Chleborad, A.F., and others, 1980 
Adams, W.D., 1972, Development in Alaska in 1971: Am. Assoc. Petroleum Geologists Bul1., v. 56, no. 7, p. 1175-1187.

Addicott, W.O., 1971, Tertiary marine mollusks of Alaska: An annotated bibliography: U.S. Geo1. Survey Bu11. 1343, 30 p.

, 1973, Neogene marine mollusks of the Pacific coast of North America: An annotated bibliography, 1797-1969: U.S. Geol. Survey Bu11. 1362.

, 1975, Lithology and palynology of the Beluga and Sterling formations exposed near Homer, Kenai Peninsula, Alaska: U.S. Geol. Survey

Open-file Rept. 75-383.

Adkison, W.L., Kelley, J.S., and Newman, K.R., 1975, Lithology and palynology of Tertiary rocks exposed near Capps Glacier and along Chuitna River, Tyonek Quadrangle, southern Alaska: U.S. Geol. Survey Open-file Rept. $75-21$

Alaska Division of Geological and Geophysical Surveys, 1973a, Aeromagnetic map, Anchorage Quadrangle, Alaska: Alaska Div. Geol. and Geophys. Surveys Open-file Rept. AOF-21, scale 1:250,000, 1 sheet.

, 1973b, Aeromagnetic map, Talkeetna Quadrangle, Alaska: Alaska Div. Geol. and Geophys. Open-file Rept. AOF-19, scale 1:250,000, 1 sheet. , 1973c, Aeromagnetic map, Talkeetna Mountains Quadrangle, Alaska: Alaska Div. Geol, and Geophys. Surveys Open-file Rept. AOF-20, scale $1: 250,000,1$ sheet.

Alaska Division of Mines and Yinerals, 1964, The great Alaska earthquake, March 27, 1964: Alaska Div. Mines and Minerals Misc. Paper 1, 3 p.

Alaska Division of 011 and Gas, 1977; 1976; 1975; 1974; 1973; 1972; 1971; 1970; and 1969: Statlstical reports.

, 1970 (updated to present), Field and facility location map, Cook Inlet area: Alaska Div. Oil and Gas map.

, 1976, Alaska petroleum production summary by fields for December 1975, in February 1976: Alaska Div. Oil and Gas Bu11., p. 23.

Alaska Geologica1 Society, 1969, West to east stratigraphic correlation section, West Foreland to Swan Lake, upper Cook Inlet basin, Alaska: 4 stratigraphic sections and 1 columnar section.

, 1970, Cook Inlet basin oil and gas fields guidebook, Alaska: 84 p.

, 1973, Road log and guide - Geology and hydrology for planning, Anchorage area.

, 1976, Recent and ancient sedimentary environments in Alaska: Alaska Geo1. Soc. Symposium, Apri1, 1975, Proceedings, p. 295. 
Alaska Dil and Gas Conservation Commission, 1978; 1979: Statistical report.

Alaska Outer Continental Shelf Dffice, 1980, Draft Environtantal Iapact Statement, lower Cook Inlet-Shelikof Strait, $0 i 1$ and Gas Lease Sale 60).

Albers, J.P., and others, 1973, Sumary petroleum and selected inineral statistics for 120 countries including of Eshore areas: J.S. Geol. Survey Prof. Paper 817, p. 149.

Alewine, R.W., and Jungels, P., 1972, A study of the 196.4 Alaskan Farthquaka using finite element and generalized inversion techniques [abs.]: bos (Am. Geophys. Union Trans.), v. 53, no. 11 .

American Petroleun Institute, American Gas Assoctation, and Canadian Petroleum dssociations, 1969 , Reserves of crude oil, natural gas liquids and natural gas in the United States and Canada as of December 31, 1968: v. 23, p. 31 .

American Stratigraphic Co., 1976, Index of logs issued, January 1, 1976: Anchorage, Anerican Strat Lgraphic Company.

Anderson, D., and others, 1973, Sediment distribution and coastal. processes in Cook Inlet, Alaska, in Proceedings of a symposium on significant results obtained from ERTS-1, v. l: Technical presentation, sect Lon B, Freden, S.C., Mercanti, E.P., and Becker, M.A., NASA, Washington, D.C., P. 1323-1337.

Anderson, G.S., 1971, Ground water exploration in Beaver Creek Valley near Kenai, Alaska: U.S. Geol. Survey Open-file Rept. 71-5.

, 1972, Aquifer test, Soldotna, Alaska: U.S. Geol. Survey Open-file Rept. 519.

Anderson, G.S., and Jones, S.H., 1972a, Water resources of the Kenai-Soldotna area, Alaska: U.S. Geol. Survey Open-file Rept. 72-2.

, 1972b, Hydrologic data of the Kenai-Soldotna area, Alaska: U.S. Geol. Survey Open-file Rept. 480.

Andreasen, G.E., Zietz, Isidore, and Grantz, Arthur, 1958, An aeromagnetic reconnaissance of the Cook Inlet area, Alaska [abs.]: Geophys. Soc. Tulsa Proc. 1957-1958, v. 5, p. 58, 1958: Am. Assoc. Petroleum Geologists Bul1., v. 42, no. 1, p. 219-220.

Ariey, Cass, and McCoy, Scott, 1977, Sidewall sample description, Atlantic Richfield lower Cook Inlet COST No. 1: Atlantic Richfield Company, 45 p. (Basic data at U.S. Geological. Survey Conservation Division, 800 A Street, Anchorage.)

Ariey, Cass, and Rathbun, Fred, 1977, Core description report, cores 1-4, Atlantic Richfield lower Cook Inlet COST No. 1: Atlantic Richfield Company, 45 p. (Basic data at U.S. Geological Survey Conservation Division, 800 A Street, Anchorage.) 
Averttt, Pau1, 1968, Total estimated remaining coal resources of the United

States: U.S. Geol. Survey Open-fille Rept.

, 1969, Coal resources of the United States, Jan. 1, 1967: U.S. Geol. Survey Bull. 1275,116 p.

, 1970, Stripping-coal resources of the United States, Jan. 1, 1970:

U.S. Geol. Survey Bull, 1322, 34 p.

, 1975, Coal resources of the United States, Jan. 1, 1974: U.S. Geol. Survey Bu1l. 1412, 131 p.

Averitt, Paul, and Carter, M.D., 1970, Selected sources of information on United states and world energy resources; An annotated bibliography:

U.S. Geol. Survey Circ. 641, p. 21.

Averttt, Paul, and Lopez, Lorreda, 1972, Bibliography and index of U.S. Geological Survey publications relating to coal, 1882-1970: U.S. Geol. Survey Bu11. $1377,173 \mathrm{p}$.

Ayres, M.G., 1964, Regional geology of the Cook Inlet area, Alaska, in Guidebook, Eield trip routes, Anchorage to Sutton, 1963; Sutton to Caribou Creek, 1964 - Dil fields, earthquake, geology, Anchorage, Alaska: Alaska Geol. Soc., p. 28-36.

Babcock, Laure1, 1977, Petrographic description of thin sections from lower Cook Inlet COST we1l: Amoco Production Co., appendix (6 p.). (Basic data at U.S. Geological Survey Conservation Division, 800 A Street, Anchorage.)

Barnes, D.F., 1962a, Geologic map of lower Matanuska Valley, Alaska: U.S. Geol. Survey Misc. Geol. Inv. Map I-359.

, 1962b, Variation in rank of Tertiary coals in Cook Inlet basin, Alaska, in Geological Survey Research 1962: U.S. Geol. Survey Prof. Paper $450-\mathrm{C}, \mathrm{p} \cdot 14-16$.

, 1966, Geology and coal resources of the Beluga-Yentna region, Alaska: U.S. Geol. Survey Bu11. 1202-C, p. C1-C54.

, 1967, Coal resources of Alaska: U.S. Geo1. Survey Bu11. 1242-B, p. B1-B36.

, 1968, Gravity map of Alaska: U.S. Geol. Survey Prof. Paper 600-A, p. A38-A39.

, 1969, Progress on a gravity map of Alaska: EOS (Am. Geophys. Union

Trans.), v. 50, no. 10, p. 550-552.

, 1976, Bouguer gravity map of Alaska: U.S. Geol. Survey Open-file Rept. 76-70, scale $1: 2,500,000,1$ sheet.

Barnes, D.F., and others, 1951, Coal investigations in south-central Alaska, 1944-1946: U.S. Geol. Survey Bu11. 963-E, p. 137-213. 
Barnes, D.F., and Ford, D.M., 1952, Coal prospects and coal exploration and development in the Lower Matanuska Valley, Alaska i.n 1950: U.S. Geol. Survey Circ. 154.

Barnes, D.F., and Sokol, Daniel, 1959, Geology and coal. resources of the Little Susitna district, Matanuska coal field, Alaska: U.S. Geol. Survey Bu1.1. 1058-F, p. 217-260.

Barnes, D.F., and Cobb, E.H., 1959, Geology and coa1 resources of the Homer district, Kenai coal field, Alaska: U.S. Geol. Survey Bull. 1058-F, p. $217-260$.

Barnes, D.F., and Miller, T.P., 1975, Geothermal studies in Alaska [abs.]: Geol. Soc. American Abs., with Programs, v. 6, no. 7, p. 645-645.

Bea, R.G. and Akky, M.R., 1979, Seismic oceanographic, and reliability considerations in offshore platform design: Offshore Technology Conf. Proceedings, v. 4, no. 11, p. 2251-2262.

Beikman, H.M., 1974, Preliminary geologic map of the southwest quadrant of Alaska: U.S. Geol. Survey Misc. Field Studies Map MF-61l, scale $1: 1,000,000,2$ sheets.

, 1975a, Preliminary geologic map of the southeast quadrant of Alaska: U.S. Geol. Survey Misc. Field Studies Map MF-612, scale 1:1,000,000, 2 sheets.

, 1975b, Preliminary geologic map of the Alaska Peninsula and Aleutian Islands: U.S. Geol. Survey Misc. Field Studies Map MF-674, scale $1: 1,000,000,2$ sheets.

Beikman, H.M., Holloway, C.D., and MacKevett, E.M., Jr., 1977, Generalized geologic map of the Cook Inlet area, Alaska: U.S. Geol. Survey Openfile Rept. 77-169-B, scale 1:1,000,000, 1 sheet.

Belon, A.E., and Miller, J.M., 1974, Applications of ERTS data to resource surveys of Alaska, in Third Earth Resources Technology Satellite-l Symposium: Vol. 1, Technical Presentations, Section B; Interpretation Techniques: NASA Spec. Publ. 351, p. 1899-1907.

Belon, A.E., and Stringer, W.J., 1975, Environmental assessment of resource development in the Alaskan coastal zone based on Landsat imagery:

NASA Tech Memo. X-58168, v. II-B, Coastal Zone Services, p. 242-260.

Bennison, A.P., 1974, Geologic highway map of the State of Alaska and the State of Hawail: Am. Assoc. Petroleum Geologists Map 8, 1:3,500,000, 1 sheet.

Berg, E., and others, 1971, Source of the major tsunami, in the Great Alaska Earthquake of 1964, Oceanography and Coastal Engineering: Nat. Acad. Sci. Pub., p. 122-139.

, 1972, Crustal structure in Alaska, in the Great Alaska Earthquake of 1964, Seismology and geodesy: Nat1. Acad. Sci. Pub., p. 8-19. 
Berg, H.C., and Cobb, E.H., 1967, Metalliferous lode deposits of Alaska: U.S. Geol. Survey Bull. 1246, p. 254.

Bettis, F., 1976, Gas detection in sands of high silt-clay content in the Cook Inlet area: Society Professional Well-Log Analysts, annual Logging Symposium Transactions, no. 17, 13 p.

Beving, R.L., 1974, Oil pollution in martime Alaska: Fairbanks, Univ. Alaska, M.A. Thesis, 49 p.

Bewley, Georgia, 1974, Natural gas fields -- Cook Inlet basin, Alaska: U.S. Bur. Mines Open-file Rept. 35-74, p. 24; also released as National Technical Information Service, PB 235 767-AS.

Bewley, Georgia, and others, 1975, Present and historical demand for oil and gas in Alaska: Alaska Div. Geol, and Geophys. Surveys Open-file Rept. AOF-90, 16 p.

, 1975, Alaskan oil demand 1975-2000: Alaska Div. Geol. and Geophys. Surveys Open-file Rept. AOF-91, 32 p. , 1976a, Oil and gas seeps in Alaska; Alaska Peninsula, western Gulf. of Alaska: U.S. Bur. Mines Rept. Inv. RI-3122, 78 p.

, 1976b, Oil and gas exploration of the Iniskin Peninsula, Alaska: U.S. Bur. Mines Open-file Rept. 69-76, 19 p.

Blasko, D.P., Wenger, W.J., and Morris, J.C., 1972, Oilfields and crude oil characteristics; Cook Inlet basin, Alaska: U.S. Bur. Mines Rept. RI-7688, $44 \mathrm{p}$.

Boettcher, R.R., 1977, Formainifera reports -- Parts I, II, III: Atlantic Richfield Company, CUST No. 1: Anderson, Warren and Associates, Inc., 38 p. (Basic data at U.S. Geol. Survey Conservation Division, $800 \mathrm{~A}$ Street, Anchorage.)

Boss, R.F., Lennon, R.B., and Wilson, B.W., 1976, Middle Ground Shoal oil fi.eld, Alaska: Am. Assoc. Petroleum Geologists Mem. 24, North American oill and gas fields, p. 1-22.

Bouma, A.H., and Hampton, M.A., 1976, Preliminary report on the surface and shallow subsurface geology of lower Cook Inlet and Kodiak Shelf, Alaska: U.S. Geo1. Survey Open-file Rept. 76-695, 36 p.

Bouma, A.H., and Wennekens, M.P., 1977, Large dunes and other bedforms in lower Cook Inlet, Alaska: Offshore Technology Conference, Preprints, no. 9, v. 1, p. 79-90.

Bouma, A.H., and Hampton, M.A., 1978, High resolution seismic profiles, side-scan sonar records, and sampling locations from lower Cook Inlet and Kodiak Shelf, R/V Sea Sounder cruise S7-77-WG, Sept.-Oct., 1977: U.S. Geol. Survey Open-file Rept. 78-727, 25 p. 
Bouma, A.H., and others, 1978a, Physiography of lower Cook Inlet, Alaska: U.S. Geol. Survey Open-file Rept. 78-728, 13 p.

Bouma, A.H., and others, 1978b, Bottom characteristics of lower Cook Inlet, Alaska: U.S. Geol. Survey Open-file Rept. 78-236, 93 p.

Bouma, A.H., and others, 1977c (1978c), Sand waves and other bedforms in lower Cook Inlet, Alaska: Mar. Geotechnology, v. 2, p. 291-308.

Bouma, A.H., and others, 1978d, Movement of sand waves in lower Cook Inlet, Alaska: Offshore Technology Conference, 10th, Houston, May 8-10, 1978 , v. 4 , no. 10 , p. $2271-2284$.

Bouma, A.H., and others, 1980, Identification of bedforms in lower Cook Inlet, Alaska, in A.H. Bouma, ed., Shallow marine processes and products Sed. Geology, v. 26, no. 1-3, p. 157-177.

Brundege, H.T., 1963, Alaska at the crossroads: World 0i1, v. 156, no. 7, p. 95-98.

Budnik, R.T., 1974a, The geologic history of the Valdez Group, Kenai Peninsula, Alaska, deposition and deformation at a Late Cretaceous consumptive plate margin [abs., University of California at Los Angeles Ph.D. dissortation]: Dissert. Abs., v. 35, no. 5, p. 2260-2261. , 1974b, Deposition and deEormation along an Upper Cretaceous consumptive plate margin, Kenai Peninsula, Alaska: Geol. Soc. America Abs. with Programs, v. 6, p. 150.

Buffler, R.T., 1976, Geologic map of South Augustine Island, lower Cook Inlet, Alaska: Alaska Div. Geol, and Geophys. Surveys Open-file Rept. AOF-96, scale $1: 48,000,1$ sheet.

Burbank, D.C., 1977, Circulation studies in Kachemak Bay and lower Cook Inlet, Alaska: Alaska Dept. Fish and Game Rept., p. 207.

Burre11, D.C., Rosenberg, D.H., and Hood, D.W., 1967, Marine geological characteristics of Cook Inlet; preliminary data on suspended sediment material: U.S. Atomic Energy Comm. unpublished annual report, Contract AT-(04-3)-310, Fairbanks, Univ. Alaska Inst. of Marine Science, p. $115-122$.

Butler, H.M., 1971, Palmer Seismological Observatory: Earthquake Notes, v. 42 , no. 1, p. $15-36$.

Cadle, R.D., Mroz, E.J., and Hobbs, P.V., 1977, Particles in the eruption cloud from St. Augustine volcano: Science, v. 199, no. 4327.

Calderon, B.H., 1969, La Exploracion y produccion petrolera en Alaska (Oil exploration and production in Alaska): Soc. Venezolana Geologos, Bol., v. 4, no. 2, p. 7-14. 
Calderwood, K.W., and Fackler, W.C., 1972, Proposed stratigraphic nomenclature for Kenai Group, Cook Inlet basin, Alaska: Am. Assoc. Petroleum Geologists Bull., v. 56, no. 4, p. 739-754.

Carsola, A.1., 1975, Oceanographic/Meteorological study of the lower Cook Inlet, Alaska: Lockheed Ocean Lah., IV.

Claypool, G.E., Threlkeld, L.N., and Magoon, L.B., Natural gas in Cook Inlet basin - biogenic and thermogenic origins: Am. Assoc. Petroleum Geologists (in prep.).

Christensen, E.W., 1977, Retrographic report, sidewal1 samples (23), 5,120 - 10,145 feet, Atlantic Richfield lower Cook Inlet COST No. 1: Chevron USA. (Basic data at U.S. Geological Survey Conservation Division, 800 A Street, Anchorage.)

Cobb, E.H., 1972a, Metallic mineral resources map of the Kenai Quadrangle, Alaska: U.S. Geol. Survey Misc. Field Studies Map MF-377, scale l: 250,000 . , 1972b, Metallic mineral resources map of the Seldovia Quadrangle, Alaska: J.S. Geol. Survey Misc. Field Studies Map MF-397, scale 1:250,000.

, 1980a, Sumary of references to mineral occurrences (other than inineral fuels and construction materials) in the Kenai and Tyonek Quadrangles, Alaska: U.S. Geol. Survey Open-file Rept. 80-86, 36 p.

, 1980b, Sumnary of references to mineral occurrences (other than mineral fuels and construction materials) in the Seldovia Quadrangle, Alaska: U.S. Geol. Survey Open-file Rept. 80-87, 47 p.

Core Laboratories, Inc., 1977a, Core analysis results, cores 1-4, Atlantic Richfield lower Cook Inlet COST No. 1: Core Laboratories, Inc. (Basic data at U.S. Geological Survey Conservation Division, 800 A Street, Anchorage.)

, 1977 b, Sidewall core analysis results, sidewall cores, Atlantic Richfield lower Cook Ine1t COST No. 1: Core Laboratories, Inc. (Basic data at U.S. Geological Survey Conservation Division, 800 A Street, Anchorage.)

Crick, R.W., 1971, Potential petroleum reserves, Cook Inlet, Alaska, in Future petroleum provinces of the United States, their geology and potential, v. 1: Am. Assoc. Petroleum Geologists Mem. 15, p. 109-119.

Conwe11, C.N., 1972a, Alaskan coals: Soc. Mining Engineers Trans., v. 252, no. 3, p. 279-282.

, 1972b, Alaskan coals may prove a big plus in future exports pictures: Mining Eng., v. 24, no. 10, p. 82-84. 
Cram, I.H., 1971, Future petroleum provinces of the United States -- their geology and potential: Am. Assoc. Petroleum Geologist, Yem. 15, p. $1-54$.

Dames and Moore, 1976, 011 spill trajectory analysis, lower Cook Inlet, Alaska: Juneau, Alaska, NOAA Outer Continental She Lf Environnenta1 Assessment Program, Bering Sea-Gulf of Alaska Project Office, job 6797-003-20, 32 p.

1979, Oil spill trajectory analysis, lower Cook Inlet, Alaska: Jineau, Alaska, NOAA, Outer Continental Shelf Environmental Assessment Program, Bering Sea-Gulf of Alaska Project Office, job 6797-011-02.

, 1979, Lower Cook Inlet and Shelikof Strait oCS lease sale no. 50 : Juneau, Alaska, NOAA Outer Continental Shelf Environmental Assessment Program, Bering Sea-Gulf of Alaska Project office, job 3599-017-20, $269 \mathrm{p}$.

, 1980, 011 spill trajectory simulation, lower Cook Inlet, Alaska: Juneau, Alaska NOAA, Outer Continental Shelf Environmental. Assessment Program, Bering Sea-Gulf of Alaska Project Office, job 6797-014-88.

Das, M.M, 1971, Longshore sediment transport rates, a compilation of data: U.S. Army Coastal Engineering Research Center, Misc. Paper 1-71, 75 p.

Davies, J., and Berg, E., 1973, Crustal morphology and plate tectonics in south-central Alaska: Seismol. Soc. America Bu11., v. 63, no. 2, p. 673-677.

Davis, T.N., and Echols, C., 1962, A table of Alaskan earthquakes, 17881961: Fairbanks, Univ, of Alaska Geophysica1 Institute Geophys. Research Rept. 8, p. 43.

Davison, K., 1963, Cook Inlet gas finds are important: World 0il, v. 157, no. 7, p. 92, 95-96.

Detterman, R.L., 1973, Geologic map of the Iliamna B-2 Quadrangle, Augustine Island, Alaska: U.S. Geol. Survey Geol. Quadrangle Map GQ-1068. , 1963, Revised stratigraphic nomemclature and age of the Tuxedni Group in the Cook Inlet region, Alaska, in U.S. Geological Survey Journal of Research, 1963: U.S. Geol. Survey Prof. Paper 316-G, p. 117-134.

Detterman, R.L., and Reed, B.L., 1964, Preliminary map of the geology of the Illlamna Quadrangle, Alaska: U.S. Geol. Survey Misc. Geol. Inv. Map I-407, scale $1: 250,000,1$ sheet.

, 1980, Stratigraphy, structure nad economic geology of the Iliamna Quadrangle, Alaska: U.S. Geol. Survey Bul1. 1368-B, 86 p. 
Detterman, R.L., Reed, B.L., and Lanphere, M.A., 1965, Jurassic plutonism in the Cook Inlet region, Alaska, in U.S. Geological Survey Journal of Research, 1965: U.S. Geol. Survey Prof. Paper 525-D, p. 16-21.

Detterman, R.L., and Jones, D.L., 1974, Mesozoic fossils from Augustine Lsland, Cook Inlet, Alaska: Am. Assoc. Petroleum Geologists Bull., v. 58, no. 5, p. 868-870.

Detterman, R.L., and others, 1974, Surface geology and Holocene breaks along the Susitna segment of the Castle Mountain fault, Alaska: U.S. Geo1. Survey Misc. Field Studies Map MF-618, scale 1:24,000, 1 sheet. , 1976a, Reconnaissance geologic map along Bruin Bay and Lake Clark faults in Kenai and Tyonek Quadrangles, Alaska: U.S. Geol. Survey Open-file Rept. 76-477, 6 p., scale $1: 250,000,2$ sheets.

1976b, Geology and surface features along Talkeetna segment of the Castle Mountain Fault system, Alaska: U.S. Geol. Survey Misc. Field Studies Map MF-738.

Dickenson, K.A., 1978, Sedimentary facies in Tertiary rocks in the Tyonek Quadrangle [abs.]: U.S. Geol. Survey Prof. Paper 1109, 84 p.

Dutro, J.T., Jr., 1960, Correlation chart of Paleozoic rocks in Alaska: U.S. Geol. Survey Open-file Rept. 60-44.

Elsik, W.C., 1973, Auriculiitites paleocenicus sp. nov. from the Palocene of Cook Inlet area, Alaska: Pollen et Spores, v. 15, no. 1, p. 135-138.

Englehardt, D.W., 1966, Rugaepollis kachemakensis, gen, et sp. nov. from the Tertiary of Alaska: Pollen et Spores, v. 8, no. 1, p. 135-139.

Estes, S.A., 1978, Seismotectonic studies of lower Cook Inlet, Kodiak Island and the Alaska Peninsula areas of Alaska: Fairbanks, Univ. Alaska, M.S. Thesis.

Evans, C.D., 1969, Environmental ef fects of petroleum development in the Cook Inlet area: Alaska Science Conference, Anchorage Proceedings, 1968, p. 213-221.

Evans, C.D., and others, 1972, The Cook Inlet environment - A background study of available knowledge: Anchorage, Univ. Alaska Resources and Science Center Alaska Sea Grant Program report for U.S. Army Corps of Engineers, Alaska district, p. 137.

Fisher, M.A., 1976a, Interpretation and description of seismic data from lower Cook Inlet, Alaska: U.S. Geol. Survey Open-file Rept. 76-561, $100 \mathrm{p}$.

, 1976b, Geology of offshore lower Cook Inlet, Alaska, from seismic data [abs.]: Am. Assoc. Petroleum Geologists Bul1. 60, no. 12, p. $2180-2181$. 
Fisher, M.A., 1977, Structure and possible petroleum traps of lower Cook Inlet, Alaska: Offshore Technology Conference, Preprints, v. 1, no. 9, p. $17-22$.

Fisher, M.A., and Magoon, L.B., 1978, Geologic framework of lower Cook Inlet, Alaska: Am. Assoc. Petroleum Geologists Bu1l., v. 62, p. 373-402.

Fogleman, K., and others, 1978, Catalog of earthquakes in southern Alaska, October-December, 1977: U.S. Geol. Survey Open-file Rept. 78-1097, $28 \mathrm{p}$.

Foster, H.L., and Karlstrom, T.N.V., 1967, Ground breakage and associated effects in the Cook Inlet area, Alaska, resulting from the March 27, 1964, earthquake: U.S. Geol. Survey Prof. Paper 543-F, p. F1-F28.

Freethey, G.W., 1978, Guide to groundwater data, Cook Inlet Basin, Alaska: U.S. Geol. Survey Open-file Rept. 78-439, 200 p.

Gatto, L.W., 1975, Circulation and sediment distribution in Cook Inlet, Alaska: International Conference of Port and Ocean Engineering under Arctic Conditions: Fairbanks, Univ. Alaska Institute Marine Science Occassional Publication 4, p. 205-227.

Gedney, Larry, and Berg, Eduard, 1969, Some characteristics of the tectonic stress pattern in Alaska: Royal Astron. Soc. Geophys. Jour. v. 17, no. 3, p. 293-304.

Gedney, Larry, and others, 1972, Correlation of epicenters with mapped faults, east-central Alaska, 1968-1971: U.S. Geol. Survey Open-file Rept., p. 7, 1 sheet.

Gi11, D., 1975a, More gas development expected in Cook Inlet: West $0 i 1$ Rep., v. 32, no. 9, p. 42-44. , 1975b, Most near future exploration will be offshore: West 0il Rep., v. 32, no. 9, p. 2-29.

Geopfert, B.L., 1969, An engineering challenge - Cook Inlet, Alaska: Offshore Technology Conference, 1st, Preprints, p. 511-524.

Grantz, Arthur, 1956, Magnetite deposits at Tuxedni Bay, Alaska: U.S. Geo1. Survey Bu11. 1024-D, p. D95-D106.

, 1964, Mineral fuel resources - southern Alaska, in Mineral and water resources of Alaska: U.S. Congress 88th 2nd session, print, p. 44-62.

Grantz, Arthur, and Zietz, Isidore, 1960, Possible significance of broad magnetic high over belts of moderately deformed sedimentary rocks in Alaska and California: U.S. Geo1. Survey Prof. Paper 400-B, p. B342-B347.

Grantz, Arthur, Zietz, Isidore, and Andraesen, G.E., 1963, An aeromagnetic reconnaissance of the Cook Inlet area, Alaska: U.S. Geol. Survey Prof. Paper 316-G, p. G117-G134. 
Gryc, George, 1971, Summary of potential petroleum resources of region 1 (Alaska and Hawai), Alaska, in Euture petroleum provinces of the United States, their geology and potential, v. 1: Am. Assoc. Petroleum Geologists Mem. 15, p. 55-67.

Hackett, S.W., 1975, Regional gravity survey of the Beluga Basin and adjacent areas, Cook Inlet region, south-central Alaska [abs.]: Society Exploration Geophysics annual international meeting, no. 45, p. 21-22.

, 1977, Gravity survey of Beluga Basin and adjacent area, Cook Inlet region, south-central Alaska: Alaska Div. Geol. and Geophys. Surveys Geol. Rept. 49, 26 p.

Haga, Hideyo, 1977, Palynology report - Parts I, II, III - Atlantic Richfield Company COST well No. 1: Anderson, Warren and Associates. (Basic data at U.S. Geol. Survey Conservation Division, 800 A Street, Anchorage.)

Hampton, M.A., and Bouma, A.H., 1979, Notes on the acquisition of high resolution seismic reflection profiles, siderscan sonar records, and sediment samples from lower Cook Inlet and Kodiak Shelf, R/V Sea Sounder Cruise S8-78-WG: U.S. Geol. Survey Open-file Rept. $7 \overline{9-1311 .}$

, 1980, Notes on the acquisition of high-resolution seismic reflection profiles, side-scan sonar records, and sediment samples from lower Cook Inlet and Kodiak Shelf, R/V Sea Sounder cruise, S8-79-WG, JulyAugust, 1979: U.S. Geol. Survey Open-file Rept. 80-985.

Hartman, D.C., Pesse1, G.H., and McGee, D.L., 1972, Preliminary report on stratigraphy of Kenai Group of upper Cook Inlet, Alaska: Alaska Div. Mines and Geol. Spec. Rept. 5, 4 p.

Hayes, J.B., and others, 1976, Contrasts between braided and meandering stream deposits, Beluga and Sterling formations (Tertiary), Cook Inlet, Alaska: in Recent and ancient sedimentary environments in Alaska: Anchorage, Alaska Geological Society Conference, p. J1-J27.

Hayes, M.O., Brown, P.J., and Michel, J., 1976a, Coastal morphology and sedimentation, lower Cook Inlet, Alaska, with emphasis on potential oil and oil spill impacts: S.C. Univ., Coastal Res. Div., Tech. Rept. $12,106 \mathrm{p}$.

, 1976b, Morphology and sediments of lower Cook Inlet, with a preliminary assessment of the impact of petroleum development [abs.]: Geol. Soc. America Bu11. v. 8, no. 6, p. 908.

Hein, J.R., and others, 1979, Clay mineralogy, fine-grained sediment dispersal, and inferred current patterns, lower Cook Inlet and Kodiak Shelf, Alaska: Sed. Geology, v. 24, no. 3-4, p. 291-306.

Hedlung, R.W., and Engelhardt, D.W., 1970, Rugaepollis fragilis sp. nov. from the Tertiary of Kachemak Bay, Alaska: Pollen et Spores, v. 12, no. 2 , p. $173-176$. 
Hiles, R.M., Gryc, George, and Dobey, P.l., 1975, Developments in Alaska in 1974: Am. Assoc. Petroleum Geologists Bu11., v. 59, no. 8, p. 1311-1321.

Hills, Mason, L., 1963a, Here's how Alaska's search for oil is going at Cook Inlet: 011 and Gas Jour., v. 61, no. 26, p. 194-198.

, 1963b, Cook Inlet basin may have several more large fields: World $0 i 1$, v. 157, no. 2, p. 77-80.

, 1963c, Petroleum exploration, Cook Inlet area, Alaska [abs.]: Jour. Petroleum Technology v. 5, no. 9, p. 977.

, 1964, Occurrences of petroleum in the Cook Inlet area, Alaska, in Geophysics and Geology: World Petroleum congress, 6th Frankfurt am Main, West Germany, 1963, Proceedings, sec. 1, p. 509-517.

Hood, A.C., Gutjahr, C.M., and Heacock, R.L., 1975, Organic metamorphism and the generation of petroleum: Am. Assoc. Petroleum Geologist v. 59, p. 986-996.

Hood, D.W., and others, 1968, Summary report on Collier Carbon and Chemical Corporation studies in Cook Inlet, Alaska: Fairbanks, Univ. Alaska, Institute of Marine Science.

Hopkins, D.M., and others, 1965, Quaternary correlations across Bering Strait: Science, v. 147, no. 3662, p. 1107-1114.

Howland, M.D., and Freethey, G.W., 1978, Selected hydrologic data related to water-table aquifer of North Kenai, Alaska: Alaska Div. Geol. and Geophys. Surveys Open-file Rept. AOF-112, scale $1: 63,360$, 1 sheet.

Imlay, R.W., 1953, Callovian (Jurassic) ammonites from the United States and Alaska, Part 2, Alaskan Peninsula and Cook Inlet regions: U.S. Geo1. Survey Prof. Paper 249-B, P. B41-B108.

, 1962a, Jurassic (Bathonian or early Callovian) ammonites from Alaska and Montana: U.S. Geol. Survey Prof. Paper 374-C, p. Cl-C32.

, 1962b, Late Bajocian ammonites from the Cook Inlet region, Alaska:

U.S. Geol. Survey Prof. Paper 418-A, p. Al-A15.

, 1964, Middle Bajocian ammonites from the Cook Inlet region, Alaska:

U.S. Geol. Survey Prof. Paper 418-B, p. B1-B61.

, 1975, Stratigraphic distribution of Jurassic (Callovian) ammonites in southern Alaska: U.S. Geo1. Survey Prof. Paper 836, 28 p.

, 1980, Middle Jurassic (Bathonian) ammonites from southern Alaska:

U.S. Geol. Survey Prof. Paper. 1091, 42 p.

Imlay, R.W., and Detterman, R.L., 1973, Jurassic paleobiogeography of Alaska: U.S. Geol. Survey Prof. Paper 801, p. 34. 
Ion, D.C., 1970, Arctic oil and the world, one perspective [abs.]: in International Symposium on Arctic Geology, 2nd: Am. Assoc. Petroleum Geologists Bu11., v. 54, no. 12, p. 2487.

Jackson, J.B., and Dorrier, R.T., 1980, Outer Continental Shelf oil and gas activities in the Gulf of Alaska (including lower Cook Inlet) and their onshroe impacts; a summary report, Sept. 1980: U.S. Geol. Survey Open-file Rept. 80-1028.

Jackson, J.B., and McIlhargey, Frank, 1980, Inventory of of fshore oil and gas facilities in Kenai Peninsula Borough: Philadelphia, Rogers, Golden and Halpern, and Kenal Peninsula Borough for the U.S. Geol. Survey, 64 p., unpublished.

Johnson, P.R., and Harman, C.W., 1969, Envirnomental atlas of Alaska: Fairbanks, Univ. Alaska Institute of Water Resources.

Johnston, D.A., 1978, Volatiles, magma mixing, and the mechanism of eruption of Augustine Volcano, Alaska: Seattle, Univ. Washington, $\mathrm{Ph}$. D. Thesis.

Johnston, D.A., Schmincke, H.U., 1977, Triggering of explosive volcanic eruptions by mixing of basaltic and silicic magmas [abs.]: Geol. Society America Abs. with Programs, v. 9, no. 7, p. 1041.

Johnstone, D.A., Schmincke, H.U., and Kienle, Juergen, 1977, The eruption of Augustine volcano, Alaska, and evaluation of the hazards for future eruptions [abs.]: Geol. Soc. american Abs. with Programs, v. 9, no. 4, p. 442-443.

Jones, B.C., 1979, Developments in Alaska in 1978: Am. Assoc. Petroleum Geologists Bu11., v. 63, no. 8, p. $1211-1222$.

, 1980, Developments in Alaska in 1979: Am. Assoc. Petroleum Geologists Bu11., v. 64, no. 9, p. 1345-1353.

Jones, D.L., 1973, Structural elements and biostratigraphical framework of lower Cretaceous rocks in southern Alaska; in the Boreal lower Cretaceous: p. 1-18 (incl. Ger., Fr., sum.), Seel House Press, Liverpool, England.

Jones, D.L., and Clark, S.H.B., 1973, Upper Creataceous (Maestrichtian) fossils from the Kenai-Chugach Mountains, Kodiak and Shumagin Islands southern Alaska: U.S. Geol. Survey Jour. Research, 1973, v. 1, no. 2, p. $125-136$.

Jones, D.L., and Detterman, R.L., 1966, Cretaceous stratigraphy of the Kamishak Hills, Alaska Peninsula: U.S. Geol. Survey Prof. Paper 550-D, P. D53-D58. 
Jones, D.L., Mackevett, E.M. Jr., and Plafker, George, 1970, Speculations on late Mesozoic tectonic history of part of southern Alaska [abs.], in International Symposium on Arctic Geology, 2nd: Am. Assoc. Petrolenm Geologists Bul1., v. 54, no. 12, p. 2489.

Jones, D.L., and Miller J.W., 1976, Preliminary geologic map of the Alaskan Peninsula, with emphasis on upper Mesozoic fossil localities: U.S. Geol. Survey Open-file Rept. 76-76.

Jones, J.M., 1980, Resource estimates for leased ocs tracts in lower Cook Inlet and northern Gulf of Alaska: U.S. Geol. Survey Conservation Division, Anchorage, memorandum, June.

Karlstrom, T.N.V., 1958, Ground conditions and surficial geology of the Kenai-Kasilof area, Kenai Peninsula south-central Alaska: U.S. Geol. Survey Misc. Geol. Inv. Map I-269.

, 1960, The Cook Inlet glacial record and Quaternary classification, in U.S. Geol. Survey Research, 1960: U.S. Geol. Survey Prof. Paper 400-B, p. B330-B332.

, 1964, Quaternary geology of the Kenai lowland and glacial history of the Cook Inlet region, Alaska: U.S. Geol. Survey Prof. Paper 443, 69 p.

,.21968, The Quaternary time scale - A scale problem of correlation and radiometric dating, in Means of correlation of Quaternary successions: International Association Quaternary Research, 7 th Congress, Salt Lake City, Utah, 1965, Proceedings, Univ. Utah Press v. 8, p. 121-150.

Kelley, J.S., 1973, Preliminary study of the heavy minerals fron cores of Tertiary rocks in the Deep Creek Unit well, Kenai Peninsula, Alaska: U.S. Geol. Surv. Open-file Rept. 73-141.

Ke1ly, J.S., and Denman, J.M., 1972, Geological 1iterature on the Alaska Peninsula and adjacent areas: Alaska Div. Geol, and Geophys. Surveys bibl. $64 \mathrm{p}$.

Ke1ly, T.E., 1963, Geology and hydrocarbons in Cook Inlet basin Alaska; Houston Geo1. Soc. Bull., v. 5, no. 10, p. 15-18.

1963, Geology and hydrocarbons in Cook Inlet basin, Alaska, in Backbone of the Americas: Am. Assoc. Petroleum Geologists Mem. 2, p. $278-296$.

, 1966, Geological characteristics of the Cook Inlet area, Alaska [abs.]: Jour. Petroleum Technology, v. 18, no. 10, [19], p. 1106.

, 1968, Gas accumulations in nonmarine strata, Cook Inlet basin, Alaska, in Natual gases in rocks of Cenozoic Age: Am. Assoc. Petroleum Geologists Mem. 9, v. 1, p. 49-644. 
Kienle, Juergen, and Forbes, R.F., Augustine Volcano research project [abs.]: Alaska Science Conference, Anchorage, Proceedings, no. 23, p. $58-59$.

, 1976, Augustine - evolution of a volcano: Eairbanks, Univ. Alaska Geophysical Institute ann. rept., 1975-76, p. 26-48.

, 1974, Alaskan volcano studies, with special reference to Augustine Volcano, in Colp, J.L., and others, eds., The utilization of volcano energy: Sandia Lab Albuquerque, New Mex., p. 205-223.

Kienle, Juergan, Harlow, D.H., 1971, Recent microearthquake swarm activity at. Augustine Volcano, Alaska [abs.]: EOS (Am. Geophys. Union. Trans.), v. 52 , no. 11 .

Kienle, Juergen, and Shaw, G.E., 1979, Plume dynamics, thermal energy and long-distance transport of vulcanian eruption clouds from Augustine Volcano, Alaska: Journal of Volcanology and Geothermal Research, v. 6 , no. $1-2$, P. $139-164$.

Kienle, Juergen, and Swanson, S.E., 1980, Volcanic hazards from future eruptions of Augustine Volcano, Alaska: Fairbanks Univ. Alaska Geophysical Institute UAG R-275, $122 \mathrm{p}$.

Kinney, P.J., Groves, J., and Bulton, D.K., 1970, Cook Inlet environmental data R/V Acona cruise 065-May 21-28, 1968: Fairbanks, Univ. Alaska Institute of Marine Science Rept. $R-70-2$.

Kirschner, C.E., and Lyon, C.A., 1973, Stratigraphic and tectonic development of the Cook Inlet petroleum province, in M.G. Pitcher, ed., Arctic geology: Am. Assoc. Petroleum Geologists Mem. 19, p. 396-407.

Kirscopp, John, Jr., 1903, The coal fields of Cook Inlet, Alaska and the Pacific coast: Institute of Mining and Metallorgy Trans., 21, p. 516-566.

Klein, R.M., and others, 1974, Energy and mineral resources of Alaska and the impact of federal land policies on their availability - oil and gas: Alaska Div. Geol. and Geophys. Surveys Open file Rept. $\mathrm{AOF}-50,18 \mathrm{p}$.

Kline, J.T., 1977, Slope map of the southern Kenai lowlands; Alaska Div. Geol. and Geophys. Surveys Open-file Rept. AOF-111C, scale 1:63,360, 1 sheet.

Knu11, J.R., 1975, Oceanography of Kachemak Bay, Alaska: Auke Bay lab manuscript Rept.-File 113.

Kuryvial, R.J., 1977, Diagenetic alteration of sandstones from lower Cook Inlet CoST No. 1: Cities Service Company. (Basic data at U.S. Geological Survey Conservation Division, 800 A Street, Anchorage.) 
Kuryvial, R.J., and Page, R.A., 1972, Hypocentral locations in the Cook Inlet region of Alaska [abs.]: EOS (Am. Geophys. Union Trans.), v. 53, no. 11 , p. 1042 .

Kuryvia1, R.J., Page, R.A., and Thomas, J.A., 1974, Catalog of earthquakes in south-central Alaska, April-June, 1972: U.S. Geol. Survey Openfile Rept. 74-1060.

LaBelle, R.P., Samuels, W.B., Lanfear, K.J., 1980, 011 spill analysis for the Cook Inlet and Shelikof Strait (proposed sale 60) Outer Continental Shelf lease area: U.S. Geol. Survey Open-file Rept. 80-863, 81 p.

Lahr, J.C., Engdah1, E.R., and Page, R.A., 1974, Locations and focal mechanisms of intermediate depth earthquakes below Cook Inlet, Alaska [abs.]: EOS (Am. Geophys. Union Trans.), v. 55, no. 4, p. 349.

Lalla, D.J., and Kienle, Juergen, 1974, Infrared radiation thermonetry of Augustine Volcano, Alaska [abs.]: EOS (Am. Geophys. Union Trans.), v. 56, no. 12 , p. 1199.

Larrance, J.D., Chester, A.J., and Milburn, H., 1979, A new sediment trap and particulate flux measurements in lower Cook Inlet, Alaska: Mar. Sci. Commun., v. 5, no. 4-5, p. 269-281.

Lathram, E.H., 1972a, Interpretation of lineaments observed on a 1971 satellite photograph of Alaska and western Canada [abs.], in Faults, fractures, lineaments, and related mineralization in the Canadian cordillera: Geological Association of Canada Programs and Abstract, Cordilleran Section, p. 16.

LeMay, W.J., 1969, A perspective on Alaska's oil potential: $0 i 1$ and Gas Jour., v. 67 , no. 8, p. $114-120$.

Lian, H.M., and Simonson, R.R., 1962, Cook Inlet basin - structure, stratigraphy, exploration techniques, logistics, discoverjes [abs.]: An. Assoc. Petroleum Geologists Bul1., v. 60, no. 13, p. 111-112.

LKB Resources, 1978, Bibliography NURE - aerial gamma ray and magnetic reconnaissance survey, Cook Inlet, Alaska area, Tyonek, Kenai, Seldovia, Anchorage, Seward, Blying Sound Quadrangles: Grand Junction Colo., U.S. Dept. Energy Rept. GJBX-108-78, various1y paginated.

Lyle, W.M., and Bragg, N.J., 1974, Coal bibliography for Alaska: Alaska Div. Geol. and Geophys. Surveys, Open-file Rept. A0F-41, 31 p.

Lyle, W.M., and Morehouse, J.A., 1977, Potential petroleum reservoir and source rocks in the Kamishak-Iniskin-Tuxedni Region, lower Cook Inlet: Alaska Div. Geol. and Geophys. Surveys Open-file Rept. A0F-104, 76 p., scale $1: 12,000,13$ sheets.

Lynch, Maurice, 1980, Activity $\log$ of drilling operations conducted in lower Cook Inlet: Anchorage, U.S. Geol. Survey Conservation Division memorandum, June. 
Mackevett, E.M., Jr., and Plafker, George, 1973, Tectonic significance of the Border Ranges fault in the western Chugach Mountains, Alaska [abs.], in Cordilleran Section, 69th Annual Meeting: Geol. Soc. America with Abstract, v. 5, no. 1, p. 76-77.

, 1974, The Border Ranges fault in south-central Alaska: U.S. Geol. Survay Journal of Research, 1974, v. 2, no. 3, p. 323-329.

Magoon, L. B., 1975, Hydrocarbon potential, geologic hazards, and the technology, time-frame and infrastructure for: exploration and development of the lower Cook Inlet, Alaska - A preliminary assessment: U.S. Genl. Survey Open-file Rept. 75-549, 75 p.

Magoon, L.B., and others, 1976, Hydrocarbon potential, geologic hazards, and infrastructure for exporation and development of the lower Cook Inlet, Alaska: IJ.s. Geol. Survey Open-file Rept. 76-449, $132 \mathrm{p}$.

Magoon, L.B., Adkison, W.L., and Egbert, R.M., 1976, Map showing geology, wildcat wells, Tertiary plant-fossil localities, $\mathrm{K}-\mathrm{Ar}$ age dates and petroleum operations, Cook Inlet area, Alaska: U.S. Geol. Survey Misc. Lnv. Map I-1019, scale 1:250,000, 1 sheet.

Magoon, L.B., and Claypool, G.E., 1978, Petroleum geology of Cook Inlet basin, Alaska [abs.]: Am. Assoc. Petroleum Geologists Bu11., v. 62, no. 7 , p. $1225-1226$.

, 1979, Petroleum Geology of Cook Inlet basin, Alaska - An exploration mode1: U.S. Geo1. Survey Open-file Rept. 79-548, 44 p.

, Origin of Cook Inlet oil: Anchorage, Alaska Geol. Society Proceedings, in press.

Yagoon, L.B., and others, 1979, Resource report for proposed oCS Sale no. 60, Lower Cook Inlet-Shelikof Strait, Alaska: U.S. Geol. Survey Openfile Rept. 79-600, 38 p.

Magoon, L.B., Hampton, M.A., Sable, E.G., and others, 1976, U.S. Geo1. Survey rates oil potential of South Cook Inlet: Oil and Gas Jour., v. 74, no. 23, p. $166-172$.

Magoon, L.B., Egbert, R.M., and Petering, George, 1978, Upper Jurassic and Cretaceous rocks of the Kamishak Hills-Douglas River area, lower Cook Inlet, in Blean, K.M., ed., The United States Geological Survey in Alaska; Accomplishments during 1977: U.S. Geol. Survey circ. 772-B, p. B57-B59.

Maher, J.C., and Trollman, W.M., 1969, Geological 1iterature on the Cook Inlet basin and vicinity, Alaska: Alaska Div. Geol. and Geophys. Surveys, bibl., 82 p.

Mckelvey, V.E., and Wang, F.F.H., 1969, World subsea mineral resources: U.S. Geo1. Survey Misc. Geol. Inv. Map I-632. 
Maloney, R.P., 1958, Reconnaissance of the Beluga River coalfield, Alaska: U.S. Bur. Mines Rept. Inv. 5430, 18 p.

Martin, G.G., Johnson, B.L., and Grant, U.S., 1915, Geology and mineral resources of the Kenai Peninsula, Alaska: U.S. Geol. Surv. Bu11. 587, 243 p.

Massoth, G.J., and others, 1979, Anomalous concentrations of particulate manganese in Shelikof Strait, Alaska; An indicator of sediment-seawater exchange processes [abs.]: EOS (Am. Geophys. Union Trans.) v. 60, no. 46, p. 852.

Mauk, F.J., and Kienle, Juergen, 1973, Microearthquakes of St. Augustine Volcano, Alaska, triggered by earth tides: Science, v. 182, no. 4110 , p. $386-389$.

McCaslin, J.C., 1976, Alaskan-shelf exploration data increasing: $0 i 1$ and Gas Jour., v. 74, no. 34, p. 159-160.

McGee, D.L., 1973, Coal reserves study, Chuitna-Beluga-Capps area, Alaska: Alaska Div. Geol. and Geophys. Surveys Open-file Rept. AOF 30, 5 p., scale $1: 5,840,3$ sheets.

, 1977, Salinity study, Cook Inlet basin, Alaska: Alaska Div. Geol. and Geophys. Surveys Geol. Rept. 54, $7 \mathrm{p}$.

McGee, D.L., and O'Connor, K.M., 1975a, Mineral resources of Alaska and the impact of federal land policies on their avallability - coa1: Alaska Div. Geol. and Geophys. Surveys Open-file Rept. A0F-51, 29 p. , $1975 b$, Cook Inlet basin subsurface coal reserve study: Alaska Div. Geol. and Geophys. Surveys Open-file Rept. A0F-74, 24 p.

McGee, D.L., and others, 1977, Bibliography of Cook Inlet, 1969-1976: Alaska Div. Geol, and Geophys. Surveys, bib1., 33 p.

McKelvey, V.E., and Wang, F.F.H., 1969, World subsea mineral resources; U.S. Geol. Survey Misc. Geol. Inv. Map I-632, 17 p., 3 sheets.

Michel, J., and others, 1978, Application of an oil spill vulnerability index to the shoreline of lower Cook Inlet, Alaska: Environmental Geology (ENGEDC), v. 2, no. 2, p. 107- 117 .

Meine1, A.B., Meine1, M.P., and Shaw, G.E., 1976, Trajectory of the Mt. St. Augustine 1976 eruption ash cloud: Science, v. 193, no. 4251, p. $420-423$.

Miller, B.M., and others, 1975, Geological estimates of undiscovered recoverable oil and gas resources in the United States: U.S. Geol. Survey Circ. 725,78 p. 
Miller, J.M., 1974, Environmental surveys in Alaska based upon ERTS data, in Third earth resources technology satellite symposium: Sumnary of results: NASA Spec. Pub1., v. 11, no. 356, p. 12-40.

Miller, J.M., and Belon, A.E., 1974, A summary of ERTS data applications in Alaska, in Ninth International Symposium on Remote Sensing of Environment: Ann Arbor, Environmental Research Institute of Michigan, v. IIt, p. 2113-2138.

Moody, J.D., Mooney, J.W., and Splvak, J.W., 1970, Giant oil fields of North America, in Geology of giant petroleun fields: Am. Assoc. Petroleum Geologists Mem. 14, p. 8-16.

Moore, H., and Everts, C.H., 1973, Tidal flat accretion in Alaska [abs.]: EOS (Am. Geophys. Union Trans.), v. 54, no. 4, p. 274.

Moulton, B., 1972, Alaska and its pipe dreams, in readings in earth sciences: New York, Van Nostrand Reinhold, p. 178-190.

Muench, R.D., Mofie1d, H.O., and Charne11, R.L., 1978, Oceanographic conditions in lower Cook Inlet, spring and summer, 1973: Jour. Geophys. Research, v. 83, no. C10, p. C5090-C5098.

Munger, A.H., ed., 1971, California-Alaska oil and gas fields: Los Angeles, Munger Map Book.

Murphy, R.J., 1977, An engineering and economic analysis of the Soldotna Creek Unit, Swanson River oil field, Alaska: Stanford Univ., Stanford Calif., M.S. Thesis.

Nationa1 Oceanic Survey, 1977, United States Coast P1lot 9: Washington, D.C., National Ocean Survey, 8th ed., Chaps. 4-6.

National Petroleum Council, 1975, Ocean petroleum resources: Washington, D.C., National Petroleum Council Rept.

National Research Counci1, 1972, The great Alaskan earthquake of 1964: Washington, D.C., Nat1. Acad. Sci.

Nee1, T.H., 1977, Both onshore and of fshore Alaska hold vast exploration potential: 0il and Gas Jour., v. 75, no. 26, p. 198-202.

Newe11, J.H., 1977a, Calcareous nonfossi1 reports - Parts I, II, III Atlantic Richfield lower Cook Inlet COST No. 1: Anderson, Warren and Assoclates, Inc. (Basic data at U.S. Geological Survey Conservation Division, 800 A Street, Anchorage.)

, 1977b, Siliceous microfossil report - Part I - Atlantic Richfield lower Cook Inlet CoST No. 1: Anderson, Warren and Assoclates, Inc. (Basic data at U.S. Geol. Survey Conservation Division, 800 A Street, Anchorage.)

Norgaard, R.B., 1972, Petroleum development in Alaska, prospects and conflicts: Natural Resources Journa1, v. 12, no. 1, p. 83-107. 
Northern Resource Management, 1980, Monitoring of1 exploration activities in the lower Cook Inlet: Anchorage, U.S. Bureau of Land Management: Alaska Outer Continental Shelf Socioeconomic Studies Program, Tech. Rept. 55.

011 and Gas Journa1, 1960, Today's active oil fronts: v. 58, no. 17, p. $148-197$.

, 1970, Alaska asks for Cook Inlet nominations: v. 68, no. 49, p. 52.

, 1971a, Alaska calls May 12 lease sale: v. 69, no. 12, p. 44.

, $1971 \mathrm{~b}$, Oral bids out, interest lags in Alaska sale: v. 69, no. 18, p. 81 .

, 1971b, Oral bids out, interest lags in Alaska sale: v. 69, no. 18, p. 81 .

, 197Jc, Huge Alaskan geophysical survey completed: v. 69, no. 49, p. 124 .

, 1972a, Court trial ends in lower Cook Inlet leasing dispute: v. 70, no. 6, p. 40 .

, 1972b, Alaskan leasing will resume in June: v. 70, no. 12, p. 36.

, 1973a, Cook Inlet bids total \$l.1 million: v. 71, p. 74.

, 1973b, U.S. to lease 15 million acres offshore: v. 71 , no. 21, p. 80 .

, 1974a, Alaska girds for series of lease sales: v. 72, no. 30,

p. 102 .

, 1974b, Wildcatting near in lower Cook Inlet: v. 72, no. 31, p. 32.

, 1974c, Socal spudding middle Cook Inlet we11: v. 72, no. 36, p. 53.

, 1974d, Alaska lease timetable near, Beaufort sea tracts included:

v. 72 , no. 43, p. 29.

, 1975a, Sales off California, Alaska sti1l set for 175: v. 73, no. 25, p. 77.

, 1975b, U.S. Given rights to lease lower Cook Inlet: v. 73, no. 26, p. 52 .

, 1975c, FPC claims say-so over Alaska LNG interstate sales: v. 73, no. 27, p. 39 .

, 1975d, Interior approved OCS-1easing speedup: v. 73, no. 41, p. 32.

, 1975 e, New rules let states preview OCS plans: v. 73, no. 45, p. 138 . 
011 and Gas Journal, 1976, U.S. Offshore frontiers: How pronising are they?: v. 74, no. 3, p. 17-22.

Osment, F.C., Morrow, R.M., and Craig, R.W., 1967, Petroleum geology and development in the Cook Inlet basin of Alaska, in Origin of oil, geology and geophysics - World Petroleum Congress, 7 th, Mexico, 1967 , Proceedings, London, Elsevier, v. 2, p. 141-150.

Page, R.A., 1968, Aftershocks and microaftershocks of the great Alaska earthquake of 1964: Seismol. Soc. America Bull., v. 58, no. 3, p. $1131-1168$.

, 1971, Measurements for fault slip on the Denali, Fairweather, and Castle Mountain faults, Alaska: Jour. Geophys. Research, v. 76, no. 35, p. $8534-8543$.

Page, R.A., and others, 1970, Geodetic triangulation for fault movement on the Denali and Fairweather faults in Alaska [abs.]: EOS (Am. Geophys. Union Trans.), v. 51 , no. 4, p. 427.

Page, R.A., and Lahr, J.C., 1972, Current seismicity in the Cook Inlet region of southern Alaska [abs], in Cordilleran Section, 68th Annual meeting: Geol. Soc. American Abs. with Programs, v. 4, no. 3, p. 214.

Paige, Sidney, and Knopf, Adolph, 1907, Stratigraphic succession in the region northeast of Cook Inlet, Alaska: Geol. Soc. America Bull., v. 18, p. $325-332$.

Payne, R.G., 1955, Mesozoic and Cenozoic tectonic elements of Alaska: U.S. Geol. Survey Misc. Geol. Inv. Map I-84.

Petroleum Data System, 1977, $0 i 1$ and gas field data, Alaska, to December 1977: Norman, Univ. Oklahoma, Petroleum Data System.

Petty, Ray, 1977, Marine high-resolution geophysical survey-lower Cook Inlet, Alaska: U.S. Geol. Survey Open-fi.le Rept. 77-358, 166 p.

Plafker, George, 1971, Pacific margin Tertiary basin, in Future petroleum provinces of North America: Am. Assoc. Petroleum Geologists, Mem. 15, p. $120-135$.

Plafker, George, and Rubin, M., 1967, Vertical tectonic displacements in south-central Alaska during and prior to the great 1964 earthquake (with discussion), in Sea level changes and crustal movements of the Pacific during the $\overline{\mathrm{P} l i o c e n e}$ and post-Pliocene time: Osaka City, Univ. Jour. Geosciences, v. 10, p. 53-66; Pacific Science Congress 1 lth, Tokyo, 1966, Symp., 19.

Plafker, George, and others, 1971, Possible future petroleum resources of Pacific-margin Tertiary basin, Alaska, in Future petroleum provinces of the United States, their geology and potential: Am. Assoc. Petroleum Geologists Mem. 15, v. 1, p. 120-135. 
Post, Austin, and Mayo, L.R., 1971, Glacier-dammed lakes and outburst floods in Alaska: U.S. Geo1. Survey Hydrol. Inv. Atlas HA-455, scale 1:1,000,000, 3 sheets.

Pulpan, Hans, and Kienle, Juergen, 1977, Seismic and volcanic risk studies, western Gulf of Alaska: U.S. Dept. Commerce, Environmental Research Lab., v. 17, p. 318-423.

Pulpan, Hans, 1979, Western Gulf of Alaska seismic risk studies: Offshore Technology Conference Proceedings, no. 11, v. 4, p. 2209-2218.

Race, W.H., 1962, The mineral industry of the Kenai-Cook Inlet-Susitna Region: Alaska Div. Mines and Minera1s Misc. publ., 42 p.

Rainwater, E.H., 1966, Exploration for natural gas, in Natural gas Institute of Petroleum Explor. and Production Group, Symposium, London, 1966, Proc.: London, Elsevier.

Rappeport, M.L., and others, 1979, Seafloor microtopography, tidal current characteristics and bottom boundary layer time series data, Cook Inlet, Alaska, [abs.]: EOS (Am. Geophys. Union Trans.), v. 60, no. 18, p. 285.

, 1981, Current meter observations within lower Cook Inlet, Alaska 1978-1979, from the R/V Sea Sounder, Pacific-Arctic Branch: U.S. Geol. Survey Open-file Rept. $\overline{81-49}$.

Reed, B.L., and Lanphere, M.A., 1969, Age and chemistry of Mesozoic and Tertlary plutonic rocks in south-central Alaska: Geol. Soc. America Bu11., v. 80 , no. 1, p. 23-43.

Reed, J.C., 1970, Oil developments in Alaska: Polar Rec., v. 15, no. 94 , p. $7-17$.

Reeder, J.W., Lahr, J.C., and Thomas, June, 1977, Seismological aspects of the recent eruption of Augustine Volcano [abs.]: EOS (Am. Geophys. Union Trans.), v. 58, no. 12, p. 1188.

Reid, J.K., and others, 1975, Summary of floods in the United States during 1969: U.S. Geol. Survey Water-Supply Paper 2030, p. 173.

Reger, R.D., 1977, Photointerpretative map of the surficial geology of the southern Kenai lowlands: Alaska Div. Geol. and Geopys. Surveys Openfile Rept. AOF 111-A, scale $1: 63,360,1$ sheet.

, 1979, Bluff Point landslide, A massive ancient rock failure near Homer, Alaska, in Short notes on Alaskan geology - 1978: Alaska

Div. Geo1. and Geophys. Surveys, Geo1. Rept. 61, p. 5-9.

Reger, R.D., and Carver, C.L., 1977, Photointerpretative map of the geologic materials of the southern Kenai lowlands: Alaska Div. Geol. and Geophys. Surveys Open-file Rept. AOF 111-B. 
Reger, R.D., and Carver, C.L., 1978a, Reconnalssance geology of the new capitol site and vicinity, Anchorage Quadrangle: Alaska Div. Geol. and Geophys. Surveys Openfile Rept. AOF 113-A, scale 1:63,360, 1 sheet.

Reger, R.D., and Carver, C.L., 1978b, Reconnaissance geologic materials map of the new capitol site and vicinity, Anchorage Quadrangle: Alaska Div. Geol, and Geophys. Surveys Open-file Rept. AOF 113-B, scale $1: 63,360,1$ sheet.

Resource Planning Team, 1974, Resources of Alaska, A regional summary, Anchorage, Alaska: Joint Fed.-State Land Use Planning Comission.

Richards, G.H., 1974, Tectonic evolutton of Alaska: Am. Assoc. Petroleum Geologist, Bull., v. 58, no. 1, p. 79-105.

Richter, D.H., and Herreid, Gordon, 1965, Geology of the Paint River area, Iliamna Quadrangle, Alaska: Alaska Div. Mines and Geology Geol. Rept. 8.

Riehle, J.R., 1977, Photointerpretative map of the surficial geology, Fox River to English Bay, Alaska: Alaska Div. Geol, and Geophys. Surveys Open-file Rept. AOF 110, scale $1: 63,360$, I sheet.

Riehle, J.R., and Emmel, K.S., 1980, Photointerpretation map of the surifical geology, Polly Creek, to McArthur River, Cook Inlet, Alaska: Alaska Div. Geol. and Geophys. Surveys Geol. Rept. 64, scale 1:63,360, 2 sheets.

Schluger, P.R., 1977, Petrographic summaries of sidewal1 cores from 1,810 4,560 Feet, Core 1 and Core 2, Atlantic Richfield lower Cook Inlet CosT No. 1: Mobil Dil Corp. (Basic data at U.S. Geological Survey Conservation Division, 800 A Street, Anchorage.)

Schmincke, H.U., and Johnston, D.A., 1977, Contrasting pyroclastic flow depostts of the 1976 eruption of Augustine Volcano, Alaska [abs.]: Geol. Soc. America Abs. with Programs, v. 9, no. 7, p. 1161.

Science Applications, Inc. 1979, Environmental assessment of the Alaskan Continental Shelf, lower Cook Inlet interim synthesis report: Boulder, Colo., NOAA.

Scu11y, D.R., Leveen L.S., and George, R.S., 1978, Surface water records of Cook Inlet basin, Alaska, thru Sept. 1975: U.S. Geol. Survey Openfile Rept. 78-498, 120 p.

Selkregg, L.L., 1974, Alaska regional profiles, south-central region: Anchorage, Univ. Alaska Arctic Environmental Information and Data Center, v. 1 .

Sharma, G.D., 1969, Sediments and tidal regimes in Cook Inlet [abs.]: EOS (Am. Geophys. Union Trans.), v. 50, no. 11, p. 636. 
Sharma, G.D., Burre11, D.C., 1970, Sedimentary environment and sediments of Cook Inlet, Alaska: Am. Assoc. Petroleum Geologist Bull., v. 54, no. 4, p. 647-654.

Shor, G.G., Ir., 1962, Seismic refraction studies off the coast of Alaska 1956-57: Seismol. Soc. America Bul1., v. 52, no. 1, p. 37-57.

studies near Kodiak, Alaska: Geophysics, v. 37, no. 4, p. 697-700.

Shore, R., and others, 1977, A study of the environmental benefits of proposed BATEA and NSPS effluent limitations for the offshore segment of the oil and gas extraction point source category: Cambridge, Mass., Energy Resource Co. Rept. 440/1-77-011, p. 375.

Sieck, H.C., and others, 1977, Analysis of high resolution seismic data, in Seismic stratigraphy, Applications to hydrocarbon exploration: Am. Assoc. Petroleum Geologists Mem. 26, p. 353-385.

Silberling, N.J., 1963, Field guide to halobiid and monotid pelecypods of the Alaskan Triassic: U.S. Geol. Survey Open-file Rept. 63-119.

Simpson, H.M., 1977, Vitrinite reflectance, Atlantic Richfield lower Cook Inlet COST No. l: Atlantic Richfield Company: Atlantic Richfield Co. (Data at U.S. Geol. Survey Conservation Division, 800 A Street, Anchorage.)

Smith, R.G., 1973, Alaskan 0.11 and national wildlife ranges: Assoc. Pacific Coast Geographers Yearbook, v. 35, p. 75-85.

Sobieralski, V.R., 1968, Volcanic activity, in Manual of color aerial photography: American Society of Photogrammetry, p. 416-417.

, 1970, Developments in Alaska in 1969: Am. Assoc. Petroleum Geologists Bu11., v. 54, no. 6, p. 1070-1083.

Stanton, T.W., and Martin, G.C., 1905, Mesozoic section on Cook Inlet and Alaska Peninsula: Geol. Soc. America Bull., 16, p. 391-410.

Stith, J.L., Hobbs, P.V., and Radke, L.F., 1977, Observations of a nuee ardente from the St. Augustine Volcano: Science, v. 4, no. 7, p. 259-262.

Story, R.F., 1966, Middle ground shoal field, Alaska [abs.]: Am. Assoc. Petroleum Geologists Bul1., v. 50, no. 3, p. 651.

Sweet, J.M., 1964, Developments in Alaska in 1963: Am. Assoc. Petroleum Geologists Bu11., v. 48, no. 6, p. 1035-1049.

Swiderski, T.J., 1977, Petrographic analysis of Cretaceous and Jurassic Samples from the lower Cook Inlet COST No. 1 well: Phillips Petroleum Co. (Data at U.S. Geol. Survey Conservation Division, 800 A Street, Anchorage.) 
Triplehorn, D.M., 1976, Contributions to clay mineralogy and petrology, Cook Inlet basin, Alaska: Alaska Div. Geol. and Geophys. Surveys opentile Rept. AOF-102, 19 p.

Tysdal, R.G., 1976, A preliminary evaluation of selected earthquake-related geologic hazards of the Kenai lowland, Alaska: U.S. Geol. Survey Openfile Rept. 76-270, 30 p.

U.S. Army Corps of Engineers, 1974, Offshore oil and gas development in Cook Inlet, Alaska: Alaska District Corps of Engineers.

, 1973, Flood plain information; Kenai River, Phase 1, Kenai Peninsula Borough, Alaska: Corps of Engineers.

, 1974, Offshore oil and gas development in Cook Inlet, Alaska:

Anchorage, Final environmental impact statement, $446 \mathrm{p}$.

, 1975, Flood plain information, Kenai River, Phase II, Kenai Peninsula Borough, Alaska.

U.S. Bureau of Land Management, 1974, Proposed increase in acreage to be offered for oil and gas lease sale no. 60:

(Alaska OCS Office), 1976, Lower Cook Inlet proposed oil and gas lease sale: 3 vol.

U.S. Bureau of Land Management, 1980, Draft environmental impact statement: Proposed OCS oil and gas lease sale no. 60: U.S. Bureau of Land

Management.

U.S. Bureau of Mines, 1973, Alaska 1:250,000 scale quadrangle map overlaps showing exploratory oil and gas well drilling locations and productive oll and gas field locations: U.S. Bur. Mines Open-file Rept. 69-73, 87 overlays (updated yearly).

U.S. Geologica1 Survey, 1969, U.S. Geological Survey heavy-metals-program progress reports, 1968 - A fleld studies: U.S. Geol. Survey Circ., 621 .

1971a, Surface water supply of the United States, 1961-65, Part 15, Alaska: U.S. Geol. Survey Water-Supply Paper, 1936.

Wills, J.C., and others, 1978, Geological and operational summary, Atlantic Richfield lower Cook Inlet, Alaska, CosT well No. 1: U.S. Geol. Survey Open-file Rept. 78-145, 48 p.

Wilson, H.M., 1972, Offshore Alaska drawing heavy geophysical outlay: Oil and Gas Jour., v. 70, no. 9, p. 17-21.

, 1974, Pending burst of leasing spel1s big Alaskan search: 011 and Gas Jour., v. 27 , no. 48, p. 25-28. 
Wilson, H.M., 1980, Cost squeeze retards Cook Inlet output: Oil and Gas Jour., v. 78 , no. 5, p. 36-37.

Wolfe, J.A., 1977 (1978), Paleogene floras fron the Gulf of Alaska region: U.S. Geol. Survey Prof. Paper 997, 108 p., 30 pl.

Wolfe, J.A., Hopkins, D.M., and Leopold, E.B., 1966, Tertiary stratigraphy and paleobotany of the Cook Inlet region, Alaska: U.S. Geol. Survey Prof. Paper 389-A, P. Al-A29.

Wolfe, J.A., and Tanai, Toshimasa, 1980, The Miocene Seldovia Point flora from the Kenai Group, Alaska: U.S. Geol. Survey Prof. Paper 1105 ,

47 p., 25 pl.

Woncik, John, 1968, Cook Inlet Basin has big stratigraphic traps: World 0 il (July), p. 144-151.

Wrenn, S.C., 1976, Eruption of Mount St. Augustine, Alaska: Anchorage, Univ. Alaska, Arctic Environmental Information and Data Center, unpublished report.

Wright, F.F., Sharma, G.D., and Burbank, D.C., 1973, ERTS-1 Observations of sea surface circulation and sediment transport, Cook Inlet, Alaska, in Symposium on significant results obtained from the Earth Resources Technology Satellite-1: NOAA, v. 1, sec. B, p. 1315-1322.

Zeitz, Isidore, Andreasen, G.E., and Grantz, Arthur, 1960, Regional aeromagnetic surveys of possible petroleum provinces in Alaska, in U.S. Geological Survey Research, 1960: U.S. Geol. Survey Prof. Paper, $400-B, p . B 75-B 76$.

Zuffa, G.G., Nilsen, T.H., and Winkler, G.R., 1980, Rock fraginent petrography of the upper Creteaceous Chugach terrane, southern Alaska: U.S. Geol. Survey Open-file Rept. 80-713, 28 p. 